\author{
Edward Fojcik \\ mgr \\ Specjalista z zakresu transportu szynowego
}

DOI: 10.35117/A_ENG_16_01_02

\title{
Railway in the Upper Silesia Coal Basin conurbation. It is time for the underground.
}

\begin{abstract}
Opportunities for a railway network to be used in present and prospective passenger transports in Upper Silesian and Coal Basin conurbation. PKP Polskie Linie Kolejowe S.A. intensions in the scope of modernization and reconstruction of railway network in the conurbation, for the purpose of functional regional and long-distance passenger transport systems' evolution. Technical and organizational conditions to separate rail passenger services from cargo transportation in the conurbation, furthermore, separating regional and long-distance rail traffic in the passenger transport. Reasons to build new railway lines connecting the conurbation center and Katowice-Pyrzowice International Airport. Courses of action for the undergrounds' process of planning at each stage in the Upper Silesian Coal Basin conurbation center, as well as regional railway lines for a local transport and a high - speed railway for a long- distance passengers' domestic and international transport.
\end{abstract}

Keywords: Railway lines; Big regional conurbations

Formed in the region of Silesian Upland, in the long process of socio - political changes and changing historical fate, Górnośląsko-Zagłębiowski urban complex is the largest conurbation in our country. It is a highly urbanized area forming part of the Upper Silesian Metropolitan Association of 13 major cities in Upper Silesia and the Basin; Bytom, Chorzow, Gliwice, Dabrowa Mining, Katowice, Mysłowice, Piekary Slaskie, Ruda Slaska, Siemianowice Slaskie, Sosnowiec, Świętochłowice, Tychy, Zabrze, forming together with Jaworzno and several directly adjacent smaller towns (Będzin, Czeladź, Radzionków), a region of the largest in our country, population density, more than three times the national average. Membership of Jaworzna the Province of Silesia and the Upper Silesian Metropolitan Union (which is an expression of the will of the people of this town) is an example of overcoming the consequences of the political division of the Polish lands from the times of the Congress of Vienna in the nineteenth century. When the First World War the borders of "Three Emperors" converged at the point of connection white and Black Przemsza in Przemsza between Mysłowice, Sosnowiec and Jaworzno. Division, the effects of the recovery by the Republic of Polish independence after World War I, were kept in the form of subsequent administrative borders of the provinces to the mid-70s of the twentieth century.

The resulting distribution in the region, a variety of natural economic development, mainly industries; coal, metallurgy, machinery, chemicals, formed a dense network of railways and roads loaded with diverse directional transport tasks both in the passenger and freight transport. In a spatially latitudinal shaped conurbation Górnośląsko - Zagłębiowska, passenger services run line diametrical Gliwice - Katowice - Zawiercie and converging near Katowice lines from other directions intersect with freight carried essentially in relations noon - midnight, as a 
result of the distribution centers industry in the region and position itself in relation to the Upper Silesia region of the country (seaports).

Currently, the high degree of urbanization and industrialization of the region requires efficient communication systems especially in the segment of passenger transport, based mainly on rail transport using primarily existing in the area of railway network of indispensable additions to the needs and the adjustments to the modern trends of development of the Silesian Province. Thus the foundation of formation of functional communication systems in the conurbation Górnośląsko - Zagłębiowska should be primarily a system of railways of the eight principal directions of transport; Czestochowa, Tunnel, Krakow, Auschwitz, Bielsko-Biala, Rybnik, Gliwice and Tarnowskie Mountains, converging on the station Katowice through neighboring stations nodal Sosnowiec Main, Myslowice, Katowice Ligota and Chorzów Batory, the indispensable additions to infrastructure in the form of a new railway line sections, stops and interchanges, and allowing the use of the tram network, bus or car parks system, "park and ride".

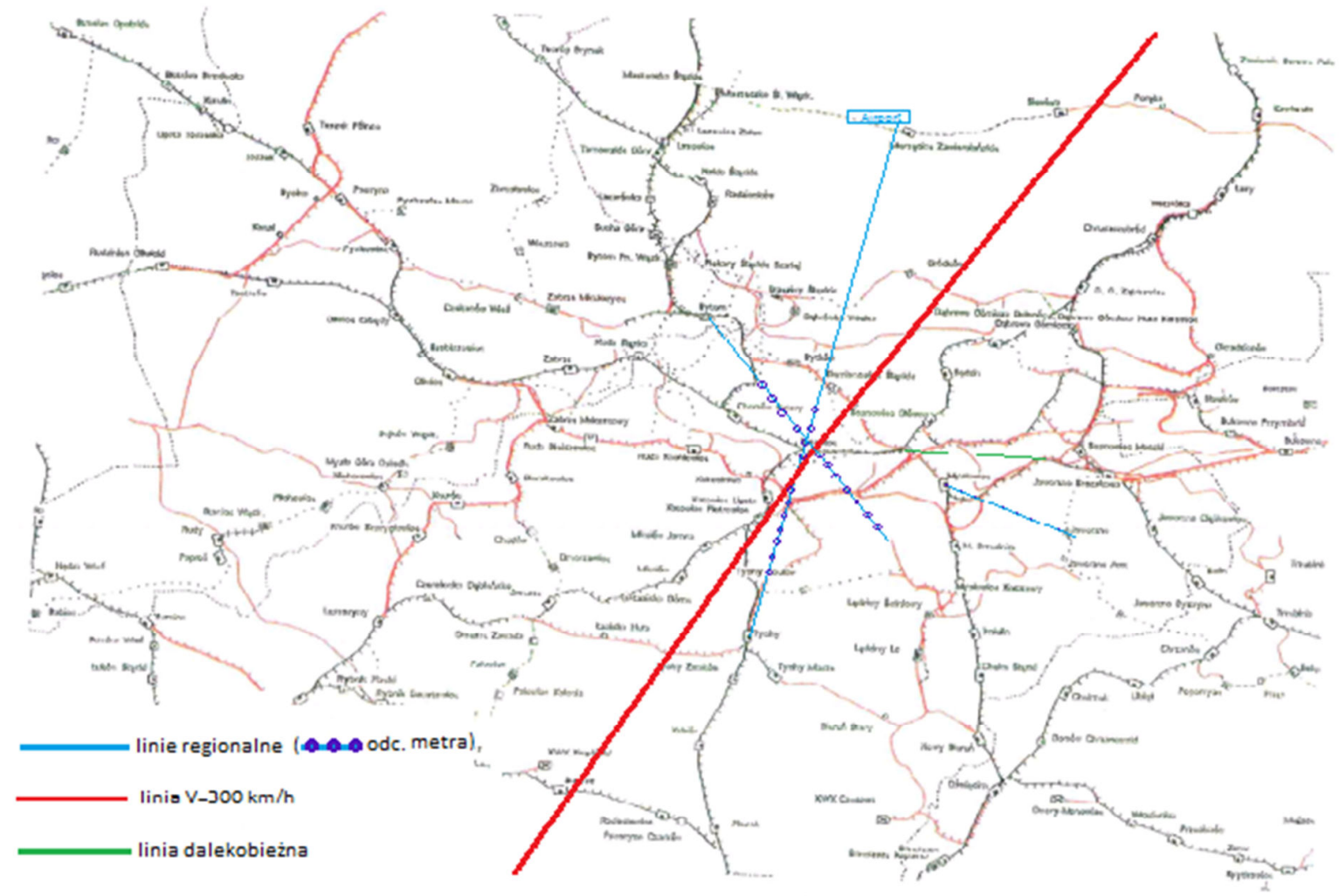

1. The course of railway lines

\section{The role of railways in the conurbation Górnośląsko - Zagłębiowska}

The usefulness of the railway network in the conurbation Górnośląsko - Zagłębiowska segment passenger can attest traffic organization trains to use the residents conurbation, introduced in the late 70's of the twentieth century. By Silesian DOKP and implemented virtually in the existing technical conditions (no separate tracks for regional traffic ), on the line Zawiercie - Katowice Gliwice cyclic frequency of trains regional (with the exception of the night) every $20 \mathrm{~min}$., (in the morning and afternoon periods of the day every $10 \mathrm{~min}$.), and on the other converging station Katowice lines with optimal the frequency of running these trains every 30 - 60 minutes. [1]. 
In this context, I would like to pay attention to public procurement PKP Polish Railway Lines S.A develop a "Feasibility study for modernization and expansion of the Katowice Railway Junction", aimed at, among others, development of technical - organizational conditions for the separation of railway lines node passenger from freight and passenger transport in the framework of regional traffic separation of long-distance mainly based on the station Katowice. Among the investment projects PKP Polish Railway Lines S.A included in the Operational Programme Infrastructure and Environment include "Construction of a new railway line, as a combination of agglomeration with Katowice to the International Airport" Katowice "in Pyrzowice". In addition, a wide range of "Feasibility study for modernization and expansion of the Katowice Railway Junction", which includes 19 projects of partial modernization of the railway junction, was established "project run high-speed line through the Katowice railway junction" of "leading (...) from Katowice in the south (the state border ) ", in reference to the crossing at the station Katowice European international railway line E 65 (North - South) and E 30 (west - east) [4], [3].

The historically formed mainly in the nineteenth century layout of the railway network in Upper Silesia draws attention - as a remnant of the former border between Germany and Russia bordering each other in this part of Europe until World War I, no railway line coming out of the node Katowice in the direction of the northern sector between the lines Katowice - Chorzów Tarnów Mountains and Katowice - Sosnowiec - Zawiercie. Attempts to overcome this division and activation of the former border were built in later years railway lines but with latitudinal course; Dabrowa Mining Ząbkowice - Brzeziny Slaskie, Zawiercie - Tarnów Mountains, or Strzebiń - Woźniki Silesian (along the line of Zawiercie - Częstochowa), designed to combine in this region rail network of Silesia and Dabrowski. Was not built, however, the railway line with meridional course (despite planned during the Second Republic of Poland because of the proximity of the border with Germany in the area of Chorzów, Piekary Slaskie, Tarnowski Mountains), which runs from the junction of the Katowice by Wojkowice in the direction of Czestochowa, resulting in today is the lack of station call the capital of the province situated to the north of the villages; Siemianowice Slaskie, Wojkowice, Czeladź, Bobrowniki, Ozarowice or International Airport "Katowice" in Pyrzowice. Do not change the situation, passenger rail services performed from Katowice lines by Katowice Profession - Katowice Dąbrówka Small Siemianowice Slaskie - Chorzow Stary - Piekary Slaskie - Tarnów Mountains (to the second half of the $60 \mathrm{~s}$ of the twentieth century.), As well as in / lines latitudinal (the 70s and 80s of the twentieth century.), because they do not allow and do not deliver for the needs of railway communication with the northern areas between the lines Katowice - Chorzów - Tarnów Mountains and Katowice - Sosnowiec - Zawiercie directly towards the capital of the province.

Among undertaken by the local government plans to improve communication in Katowice and wider scale in the area of Silesian Province undoubtedly contemporary trends in this field of socio - economic development in large metropolitan urban or conurbations, justified primarily to improve public transport, the spine should be an efficient system of transportation rail, alleviating congestion also progressing on the road. Thus a very important element in the development of public transport in spatial shaping conurbation Górnośląsko - Zagłębiowska is to use primarily the possibility of a network of railway lines converging at the station Katowice, supplemented by the missing rail connection from Katowice International Airport "Katowice" in Pyrzowice.

\section{The new railway line from the center of the conurbation to the International Airport "Katowice" in Pyrzowice beginning of the metro network}

Particularly it is worth noting that among examined concepts connections between Katowice and the International Airport "Katowice" in Pyrzowice in the form of tens of kilometres long 
construction new sections of railway lines using pieces of existing circular railway lines: "Western" approach by Chorzów or "eastern" approach by Sosnowiec - Będzin, do not exclude alternative of establishing a direct line of regional North - South length of $25 \mathrm{~km}$, connecting the airport in Pyrzowice and Katowice as the Siemianowice Slaskie (in the course similar to the concept of high-speed railway $\mathrm{V}=300 \mathrm{~km} / \mathrm{h}$. Warsaw - Katowice) the tunnel carrying the line in a metro area of dense urban northern, central and southern districts of Katowice with the further course of the ground in the direction of Tychy [2].

The proposed railway line to the International Airport "Katowice" in Pyrzowice can be carried out with the use of brownfield sites in the vicinity of the town of Siemianowice Slaskie, Dąbrówka United or Sands, with possibly a tunnel crossing the line into the hills on the south side Pyrzowic in the direct vicinity of airports (preferably with platforms at plate terminal arrangements) and a reference to the currently inactive on that section of line in the direction of Zawiercie in the area of the former station Mierzęcice. For carrying out summary of the railway line from Katowice to the airport in Pyrzowice proposed route speaks also justified the need for revitalization of north of Katowice between the lines Katowice - Chorzów - Tarnów Mountains and Katowice - Sosnowiec - Zawiercie, which is currently the largest in the conurbation area without rail passenger transport. Undoubtedly, given the need to provide reliable passenger transport, railway line connecting the center of the conurbation to the airport should be specialized for the transport with high-speed double-track line (with appropriately spaced checkpoints traffic), allowing the movement of trains at high frequency and short travel time. It is noteworthy that the combination of the proposed railway line from Katowice to the airport in Pyrzowice in the area of Mierzecice, from the currently inactive on this section line in the direction of Zawiercie, would shape the future of the modernization of this section of the regional flight from Tychy - Katowice - International Airport " Katowice "in Pyrzowice - Zawiercie, with possible connections in the direction of Czestochowa, Kielce or even Warsaw.

The most important element of the proposed solution is to carry out the railway line from the International Airport "Katowice" in Pyrzowice towards Tychy in the area of urban development of Katowice in the tunnel as the metro line, (according to the modern trends in the development of the railway network in large urban areas - Frankfurt / M , Leipzig, Stuttgart or Łódź) with a further extension of the ground in the direction of podg. Mąkołowiec and the second track was added to the regional traffic station Tychy (assumed in assumptions "Feasibility Study ..." [4]). Subterranean execution of this railway line in the area of Katowice, will first of all avoid expensive in any building solutions collision with the existing compact urban buildings and the ground and the "plate" infrastructure of various urban facilities (sewer, cable networks, etc.). Behind the tunnel carrying the line in the area of Katowice, also speaks strongly folded on the north - south axis of the city terrain, cut by transverse valleys of local rivers draining the water in the Vistula and the Oder. Through situated in the Silesian Upland Katowice runs for watershed basin of the Vistula and the Oder. Between the valleys of the rivers draining the water in the direction of the Vistula; Rawa and in the central galaxy in the southern part of the city, lies the valley Kłodnica flowing into the Odra, which makes local watersheds between the rivers run hill ranges, shaping several dozen significant differences in altitude in the area of the city. The spatial location of Katowice also notes extended longitudinally, a band-shaped area of urban development, which is a consequence of the deployment of a number of districts along the north and south axis.

Conducting in the area of the Katowice regional lines the north - south tunnel as the metro line already from the area of Siemianowice Slaskie (due to terrain conditions) under the northern (Wełnowiec) and central districts of the city (including the platforms at the station Katowice), 
and in southern districts: Brynów, Ligota, Piotrowice, Kostuchna, Podlesie (in the axis close to the course of the street to them. Army), with more stops (at around 1000-1500 m) and interchanges to other means of transport, definitely increase the availability of railway communication in the area of urban development (in relation to running the western rim of the southern districts of Katowice existing railway line in the direction of the station Tychy), enabling the achievement of the airport in Pyrzowice to the interchange in the center of the conurbation in $25-30 \mathrm{~min}$.

In the longer term development of the metro network, an important addition to taking into consideration the deployment of dense urban development and the location of the institutions in the central and peripheral areas of the conurbation, would be line; Slaski Stadium - Os. Millennium - Railway station - Provincial Office - Os. Paderewskiego - Valley "Three Ponds" Giszowiec (with a possible extension of the line in the direction of neighboring towns such. Chorzow), as well as the demarcation according to revealing the needs of formation of functional connections growing region other lines, the densely populated areas devoid of passenger rail.

It is worth mentioning that the possible extension of the diagonal line; Giszowiec Regional Office - Railway station - Os. Millennium - Slaski Stadium in the Chorzów - Bytom, allow direct passenger traffic local independent line in the direction of transport, freeing the center of the conurbation of the current line for the transport of long-distance or freight, according to the assumptions of the modeling section this line of Bytom by Chorzow Stary Northern Katowice Szopienice - Myslowice (which is part of the northern line of goods peripheral node of Katowice) of the common course of major European freight routes for combined transport CE 30, and CE 65.

\section{Assumptions of forming the railway network of regional passenger}

In PKP Polish Railway Lines S.A order, concering the development of "Feasibility study for modernization and expansion of the Katowice Railway Junction" [4], it was assumed, among others, development of technical - organizational conditions for the separation of railway lines conurbation passenger from freight and passenger transport in the framework of regional traffic separation of long-distance based mainly on the station Katowice.

According to the directional assumptions of the order authors in the development of the above-mentioned "Feasibility Study ..." should shape in the central regions of the Katowice railway junction in the first place (using a track system Katowice supplemented assumed directional introduction of railway line from Sosnowiec and Mysłowice), extracted from movement of long-distance trains, double-track lines of traffic regional trains on sections:

- Gliwice - Katowice - Zawiercie,

- Tychy - Katowice - Mysłowice,

with many more stops on these lines.

Undoubtedly, build much more stops for the double-track lines would be facilitated in an external location platforms at the tracks regional traffic, which supports the code system tracks the movement of long-distance and regional to the common four-track sections of those lines on the approaches to the station Katowice, which tracks the regional spread are - where it is justified - on the outside of the track of long-distance.

According to the authors of assumptions "Feasibility Study ..." system separated from traffic long-distance trains, double track line traffic regional trains in the indicated sections would allow for (quote) "The creation and launch of the initiative of the Marshal's Office in the Upper Silesian agglomeration network connections agglomeration ( fast regional line - SKR or fast urban line - SKM)", in the dimension of the railway communication system assumes; 
traffic organization trains running on individual lines in a fixed relationship with the transport equal frequency and desired range communication conditions on specific points of the railway network in the repetitive time sequences.

The noticeable, however, practice of operating a regional carrier which are Silesian Railways, trains relationship transport from Tychy (in existing conditions without separate tracks regional traffic) are carried out not to Myslowice (I think it is because ofthe lack of such a targeted stream of travellers), but the line of Sosnowiec - Dabrowa Gornicza - Zawiercie, on top of the basic relationship on the line shipping Gliwice - Katowice - Sosnowiec - Zawiercie Czestochowa. This circumstance may call into question the desirability of the assumed forming a four track of the railway line on the sections Tychy - Katowice - Myslowice for the separation of regional traffic, since in practice the operational no such conurbation relationship transport, most likely due to the small local stream travelers on a short section only and Myslowice, not balancing the stream of travelers from section Katowice - Tychy.

Separation of regional traffic in the form of a double-track railway line for the traffic on sections of Tychy - Katowice - Myslowice requires construction in difficult terrain four-track system in the area of Katowice (with the need to expand the so-called. "Brynowski ditch " with plenty of viaducts) on section Katowice - Brynów Podgorny - Katowice Ligota station towards Mąkołowiec Podgórny (due to the removal of track long-distance and regional traffic from the directional track system Katowice to Brynów Podgórny) in combination with inevitable reconstruction of the station Katowice Ligota also in relation to the desired exit code (planned in the assumptions), the second track of the railway line to Rybnik.

Different from assumptions of "Feasibility Study ...", proposed to carry out in an urban area of Katowice (in the form of a meter) new regional line of Tychy, acquiring existing track section Katowice - Tychy essential part of local transport in this direction, eliminating the assumed need to adjust the existing track system that section for the carriage, with far-reaching revision of assumptions and resignation from the construction in difficult terrain four-track system this line in the area of Katowice.

Formation of a four track section Tychy - Katowice - Myslowice also requires a deep reconstruction of the railway line "on east from Katowice" - system, which is a remnant of the influence of German - Russian border (up to World War I), the course of the railway line between Katowice, Sosnowiec and Mysłowice you need to improve the integration has already been seen 75 years ago (of course, starting with a completely different geopolitical reasons).

Revealing in the conurbation Górnośląsko - Zagłębiowska legitimate need for separation of railway lines for passenger transport (regional and national) and freight, indicate the need to update and verify the assumptions of modernizing existing railway network in the east of Katowice, causing inevitable gigantic reconstruction converging in the node Mysłowice; E 30 line (with proposed in the "Feasibility Study ..." separate tracks "traffic agglomeration" to Myslowice), and the northern and southern bypass goods node Katowice, as well as the same Mysłowice node.

Modern premises modify assumptions of modernize the railway network "east from Katowice" in the direction of separation line for passenger transport (regional and national) and commodities taking into account the prospects of development of railway transport in the conurbation and the same conurbation is supported, among others, behind:

- The abbreviation for "straightening" line of long distance traffic in the direction of Krakow, the southern districts of Sosnowiec (the term for the high speed V $=300 \mathrm{~km} / \mathrm{hr}$. west - east), 
- extension of the existing railway line from Katowice through Myslowice for at least the center of Jaworzno for regional traffic, (in order to obtain a desired by the inhabitants of the conurbation rail link) [2],

- shaping optimal connections commodity bypasses (north and south) junction of the Katowice station Myslowice line C-E 65/2 Częstochowa - Zawiercie - Podgórna Dorota - Sosnowiec jęzor Mysłowice Brzezinka, through the station; Sosnowiec Jęzor (direction Zawiercie - Czestochowa and Slakow Południowy (LHS) and Myslowice Brzezinka (direction Oświęcim - Kraków / Zebrzydowice - state),

which essentially simplify (due to the connection station Myslowice only track freight line) benefits under "Feasibility Study ..." rebuilding Mysłowice node and mutual system converging on the station railway lines serving the movement of freight [2].

In case of modeling the existing railway line in the direction of Oswiecim quite rightly for freight traffic (CE 30, and CE 65!), regional passenger services from this node towards the center of the conurbation (Katowice), you can shape the line by Tychy, or in relation to the tip of the proposed metro line in Giszowiec area.

The development of rational solution of the railway line east of Katowice, in order to form functional specialized railway lines serving consignments of passenger (including high-speed line $\mathrm{V}=300 \mathrm{~km} / \mathrm{hr}$. east - west, Krakow - Katowice - Wroclaw - Dresden) and commodities requires depth studies over the course of the railway lines in this area in accordance with the recognized current and future transportation needs and also puts into question the desirability of the assumed forming of the four-track railway line on section Katowice - Myslowice in addition to the unfortunate termination zone of regional traffic in Myslowice.

There are also circumstances in favour of the evolution of Tychy connection with the subway line north - south and Katowice International Airport "Katowice" in Pyrzowice, instead of doubling the railway line from Katowice via Brynów Podgórny - Katowice Ligota to Mąkołowiec Podgórny or to Myslowice.

Proposed in the conurbation Górnośląsko - Zagłębiowska new railway connections; the International Airport "Katowice" in Pyrzowice in the form of a line of regional of south - north of Tychy by Katowice - to the airport, or in consequence of the extension line of the regional center of Jaworzno, as well as the output subway line in the direction of Chorzów - Bytom, complemented by other potential underground lines in the central areas of the conurbation, would significantly delete existing deficiencies of passenger rail between the center of the conurbation and the airport or other places devoid of passenger rail (Siemianowice Sl., Czeladź, Jaworzno city center), improving the local transport to the directions with unfortunate Running for passenger rail lines, burdened in addition diverse transport operations, mainly trademarks (Bytom, southern districts of Ruda Slaska and Zabrze).

\section{Variants of the circular railway line connecting the center of the conurbation with the International Airport "Katowice" in Pyrzowice}

In light of these considerations should be skeptical refer to the proposal for forming connections between Katowice and the International Airport "Katowice" in Pyrzowice trace inactive or not existing railway lines with a very distant circular driveways for Zawiercie $(70 \mathrm{~km})$ or Tarnowskie Mountains $(55 \mathrm{~km})$, due to non-functionality on these two and even three times longer than road freight direct line, do not allow to achieve the basic goals and objectives which the line connecting the center of the conurbation to the airport must comply; - short travel time and possibly a high frequency of trains, requiring respectively specialized for these transport (passenger traffic only) railway's high-speed. 
First of all formation of railway connections Katowice Airport in Pyrzowice by Zawiercie and Tarnowskie Mountains in reference to the course of defunct or inactive, do not correspond to the requirements of functional and reliable transport, single-track sections of the former railway line Zawiercie - Tarnów Mountains, practically requires the construction of at least 20 - 25 kilometer double-track new episodes access from Tarnów Mountains or Zawiercie to this airport.

Particularly rail link through Zawiercie $(70 \mathrm{~km})$ requires regardless of a thorough reconstruction (supplement) of the track on section Zawiercie - Pyrzowice, the comprehensive construction of the second track from Zawiercie to Pyrzowice length of at least $25 \mathrm{~km}$ in order to form indispensable for these transport two-track line with appropriately spaced systems retarders intermediate stations and the end and stops. A long way to transport coupled with the need to change direction with the change of face train station Zawiercie (its omission does not meet the communication functions may be social reasons rationally unacceptable), shapes the travel time (including a stop at stations and stops in between) far in excess of 1 hour (about 75 - $80 \mathrm{~min}$.), which basically disqualifies a combination of this by rail to 25 kilometer distance to the airport from the center of Katowice. Geographical reference railway road from the center of the conurbation which they are Katowice to International Airport "Katowice" in Pyrzowice via Zawiercie makes for almost 50 minutes travelling to Pyrzowice Airport depart from the airport to overcome the first $43 \mathrm{~km}$ separating Katowice from Zawiercie and only after a change in the direction (the change in the front of the train) to enter the few kilometers long stretch leading to Pyrzowice.

Also the connection via Tarnowskie Mountains requires a complex construction of a new double-track railway line from Tarnów Mountains Airport length of about $20 \mathrm{~km}$ (in slipstream similar to the course of years now disused single-track railway line) with an appropriately spaced stations and stops. Shape connection requires a large reconstruction of the track system in the area of the station Tarnowskie Mountains resulting from the need to connect the new line from direction of the airport Pyrzowice via marshalling layout tracks this station with carbon bus line. Restoration of the "old" incorporation line from the airport to the main line in the region of Silesian towns, triggering a change of direction with a change the front of trains, also requires reconstruction in the area of the exit of the head turnout marshalling Tarnów Mountains station. Any formation of the "eastern" bypass marshalling system Tarnowskie Gory station with a new line from the direction of Naklo Silesia towards the airport in the course similar to the narrowgauge line to Chechło, "cut off" the current platforms of the Tarnów Mountains station from the new possible carry out the proposed line of travel in the direction of Pyrzowice.

Estimated travel time in this way loaded with a large movement of freight trains at high risk of the negative impact of these trains on the movement of passenger trains to and from Tarnów Mountains (including going to the airport), low speed trains in the area of the node Bytom (30 km / hr.) Also significantly exceeds one hour (about 90 - 100 minutes).

I think that the cost of building a direct abbreviated (about $25 \mathrm{~km}$ ) line of the north south from Katowice with the use of brownfield sites in the region of the village of Sands, Dąbrówka Wielka or Siemianowice Slaskie, allowing achieve goals - fast (during 25 - 30 min), good connection airport in Pyrzowice and meeting the desired communication features in the center of the conurbation Górnośląsko - Zagłębiowska with the activation areas north of Katowice, devoid of the current railway lines serving consignments passenger will be much greater than the costs of building new sections of line from the direction of Zawiercie (25 - 30 $\mathrm{km})$, or Tarnowski Mountains $(20-25 \mathrm{~km})$ and so do not meet the expectations associated with fast access to the center of the conurbation to the International Airport "Katowice" in Pyrzowice. 


\section{High-speed lines of the rail network conurbation}

In the perspective assumed in the above-mentioned "Feasibility study for modernization and expansion of the Katowice Railway Junction", it should be emphasized very important reasons to improve the functioning and quality of passenger transport in the area of the conurbation Górnośląsko - Zagłębiowska, resulting also from the implementation of concepts high-speed line $\mathrm{V}=300 \mathrm{~km} / \mathrm{h}$. ., (enabling the railways to compete effectively over long distances with air transportation), with reference to the course of international railway lines in major pan-European transport corridors E 30, E 65 crossing in the center of Katowice conurbation.

Among the sought-running direction of the high speed line in the central areas of the conurbation to the north - south axis, it should be emphasized rationality shape of the line from Warsaw during the $\mathrm{E}$ 65 in the extension of CMK from the area of Mount Włodowskiej to the state border with the Czech Republic in the area of the Moravian Gate in the direction of Vienna (E 65), Rome, the shortest route via Katowice, from tunnel (the above-mentioned reasons dot. line from the International Airport "Katowice" in Pyrzowice towards Tychy) carrying this line in the area of compact urban Katowice [2]. Detailed solutions of mutual course of the high-speed ( $\mathrm{V}=300 \mathrm{~km} / \mathrm{hr}$.), The north - south line and subway tunnels under the city buildings Katowice require further study in order to develop a rational course of these lines before under and behind the station Katowice from location of the platforms of new lines very functional layout under the existing system-sectoral this station. There is also the fundamental role of the Katowice station in the organization of passenger transport in the center of the entire conurbation and focus on this station "traffic with a change " from eight converging rail lines, subway lines next, as well as with other non-rail public transport.

With the carrying out of the new line $(\mathrm{V}=300 \mathrm{~km} / \mathrm{h})$ west - east corridor E 30 from Dresden - Wroclaw with reference to the existing track system Katowice axis west - east, with western approach to the station Katowice and exit lines new "upright "course in the direction of Krakow should not be spatial problems. Important for the functionality of the railway junction in Katowice would be out of high speed lines the north - south tunnel in the vicinity of the station Katowice Ligota to form a connection, enabling the "transition" from the station Katowice on line $\mathrm{V}=300 \mathrm{~km} / \mathrm{h}$ the north - south (and in the opposite direction ) for the possible relationship of transport (eg. Krakow - Katowice - Prague and Vienna), as well as for technological needs arising from the necessity of linking the line with the existing rail network.

\section{Summary}

Presented by PKP Polish Railway Lines S.A, assumptions develop a "Feasibility study for modernization and expansion of the Katowice Railway Junction", point to the possibility of forming the desired functional railway network serving most of all consignments of passenger according to the directions of development of the conurbation Górnośląsko - Zagłębiowska.

Possibilities of perspective, the gradual development of communication supported by European Union funds, starting in the first place from the conduct of the new direct railway line connecting the center of the conurbation with International Airport "Katowice" in Pyrzowice in relation to all possible lines of "underground" in the downtown area of Katowice extended line regional Tychy and railway high-speed passing through the center of the conurbation to the north - south axis and on the east - west axis, or the other to achieve your goals - fast, efficient connection of potential directions of transport and fulfilling the desired communication features in the conurbation Górnośląsko - Zagłębiowska, speak already the search for solutions to the initial course of these lines to reserve land for the design of new lines.

I think that for this purpose it is worth with a common effort of the Upper Silesian Metropolitan Association used under the supervision of constructive provincial and municipal 
local government, undertaken by PKP PLK SA directions for the modernization and extension of Katowice Railway Junction serving primarily the development of regional and long-distance railway traffic in Katowice and in Silesia. These are tasks that go beyond this time and the next decade, but that the effects were possible for a dozen or a few decades, the implementation of these projects need to be taken today.

\section{Source materials}

[1] Bednarczyk M. "Koncepcja zmian w organizacji ruchu pasażerskiego w Katowickim Węźle Kolejowym" Eksploatacja Kolei nr 4/1980.

[2] Fojcik E. "Kierunki rozwoju Katowickiego Węzła Kolejowego". Przegląd Komunikacyjny nr $10 / 2012$.

[3] Fojcik E. "Główne międzynarodowe linie kolejowe AGC/AGTC w obszarze Górnego Śląska" Przegląd Komunikacyjny nr 3-4/2011.

[4] Specyfikacja istotnych warunków zamówienia publicznego, PKP Polskie Linie Kolejowe S.A. Centrum Realizacji Inwestycji Oddział w Katowicach 2011 r. 